\title{
Patterns in nutrient limitation and chlorophyll $a$ along an anthropogenic eutrophication gradient in French Mediterranean coastal lagoons
}

\author{
Philippe Souchu ${ }^{1, *}$, Béatrice Bec ${ }^{2}$, Val H Smith ${ }^{3}$, Thierry Laugier ${ }^{1}$, Annie Fiandrino ${ }^{1}$, Laurent \\ Benau $^{1}$, Valérie Orsoni ${ }^{4}$, Yves Collos ${ }^{2},{\text { André } \text { Vaquer }^{2}}^{2}$ \\ ${ }^{1}$ Ifremer, Laboratoire Environnement Ressource Languedoc-Roussillon, BP 171,Avenue Jean Monnet 34203 \\ Sète Cedex, France \\ ${ }^{2}$ Université Montpellier 2, CNRS, Ifremer, UMR 5119 Ecosystèmes Lagunaires, CC093, 34095 Montpellier Cedex \\ 5, France \\ ${ }^{3}$ Department of Ecology and Evolutionary Biology, University of Kansas, Lawrence 66045, USA \\ ${ }^{4}$ Ifremer, Laboratoire Environnement Ressource Corse, Immeuble Agostini, Zone industrielle de Furiani, 20600 \\ Bastia, France
}

*: Corresponding author : P. Souchu, Phone: (33) 02- 40-37-41-96, Fax : (33) 02-40-37-40-01, email address : psouchu@ifremer.fr

\begin{abstract}
A cross-ecosystem comparison of data obtained from 20 French Mediterranean lagoons with contrasting eutrophication status provided the basis for investigating the variables that best predict chlorophyll a ( $\mathrm{Chl} \mathrm{a)} \mathrm{concentrations} \mathrm{and} \mathrm{nutrient} \mathrm{limitation} \mathrm{of} \mathrm{phytoplankton} \mathrm{biomass} \mathrm{along} \mathrm{a}$ strong nutrient enrichment gradient. Summer concentrations of dissolved inorganic nitrogen (DIN) and phosphorus (DIP) comprised only a small fraction of total nitrogen (TN) and total phosphorus (TP). On the basis of inorganic nutrient concentrations, the most oligotrophic lagoons appeared to be phosphorus-limited, with a tendency towards the development of nitrogen limitation as eutrophication increased, as evidenced by decreasing DIN:DIP ratios. A weak but significantly positive relationship was found between dissolved silicate (DSi) and Chl a, reflecting DSi accumulation in the water column along the trophic state gradient and implying a progressive shift away from potential Si limitation of phytoplankton growth. Observed concentrations of $\mathrm{Chl}$ a were far better explained by TN and TP than by DIN and DIP concentrations, suggesting that a total nutrient based approach is likely to be the most appropriate for managing eutrophication in Mediterranean lagoons and other coastal waters. These results give credence to the idea that marine and freshwater environments respond in a similar fashion to nutrient enrichment.
\end{abstract}

Résumé : Une comparaison inter-sites des concentrations de nutriments et de chlorophylle $a(\mathrm{Chl} a)$ issues de 20 lagunes de Méditerranée française de degrés divers d'eutrophisation a été menée afin de rechercher la meilleure variable expliquant le niveau de $\mathrm{Chl}$ a et d'explorer la limitation de la production primaire par les nutriments au long d'un fort gradient d'enrichissement en azote et phosphore. En été, l'azote et le phosphore inorganiques dissous (DIN et PID respectivement) constituaient une faible fraction des concentrations d'azote et de phosphore totaux (TN et TP respectivement). Sur la base des concentrations en nutriments inorganiques, la plupart des lagunes oligotrophes semblaient limitées par le phosphore avec une tendance vers des rapports DIN:DIP décroissants, et donc une limitation par l'azote, lorsque l'eutrophisation augmentait. Une corrélation positive mais faible a aussi été obtenue entre les concentrations de silicates (DSi) et $\mathrm{Chl}$ a, indiquant une accumulation de DSi dans la colonne d'eau et donc une diminution de la limitation de la croissance du phytoplancton par la silice au fur et à mesure que l'eutrophisation augmentait. Le fait que Chl a était beaucoup mieux expliquée par TN et TP que par DIN et DIP suggère même que l'approche limnologique basée sur l'ensemble des nutriments est vraisemblablement la meilleure pour gérer l'eutrophisation dans les lagunes méditerranéennes et dans d'autres écosystèmes marins côtiers. Ces constats renforcent l'idée que les écosystèmes marins et d'eau douce répondent de façon similaire à l'enrichissement en nutriments. 


\section{Introduction}

The over-enrichment of lakes, inland water courses and coastal waters with nitrogen $(\mathrm{N})$ and phosphorus (P) has been one of the major effects of human activity on aquatic ecosystems during the past fifty years (Nixon 1995; Cloern 2001). Cultural eutrophication presents a major problem for most of Europe's regional seas, including the Mediterranean (Ignatiades 2005). However, most eutrophication-related problems in the Mediterranean region currently are confined to limited areas, rather than being widespread phenomena (European Environment Agency 1999). For example, Mediterranean coastal lagoons exhibit a wide range of trophic states, and reductions in anthropogenic $\mathrm{N}$ and $\mathrm{P}$ inputs will be necessary in order to attain the desired levels of water quality that have recently been specified by the Water Framework Directive for European water bodies (European Economic Community 2000).

Historically, $\mathrm{N}$ has been considered to be the primary growth-limiting nutrient in marine ecosystems (Ryther and Dustan 1971), and phosphorus to be the principal limiting nutrient in lakes (Schindler 1977). However, this paradigm has been increasingly called into question in recent years as evidence has accumulated for widespread occurrences of both $\mathrm{N}$ and $\mathrm{P}$ limitation in lakes and streams (Elser et al. 1990; Elser et al. 2007; Lewis and Wurtsbaugh 2008), as well as frequent phosphorus limitation in the oceans (Downing et al. 1999; Elser et al. 2007). Downing et al. (1999) have observed through bioassay experiments that phosphorus limitation was strongest in unpolluted ecosystems, while limitation due to $\mathrm{N}$ was more frequent in relatively polluted coastal waters.

In marine waters, measurements of dissolved inorganic nitrogen, phosphorus and silicate concentrations (DIN, DIP and DSi respectively) are often used as a measure of eutrophication status, and ratios between dissolved nutrients have long been used to indicate which of these three nutrients is likely to be growth-limiting (Fisher et al. 1995; Justić et al. 1995). In contrast, total nitrogen (TN) and phosphorus (TP) are considered to be the best indicators of 
eutrophication status and nutrient limitation in freshwater lakes and rivers (Dodds 2003). However, this more limnological approach using relationships between phytoplankton biomass and total nutrients has been applied to marine waters with success to predict eutrophication (Downing 1997; Meeuwig et al. 2000; Smith 2003), suggesting a common response of marine and freshwater systems to nutrient enrichment (Guildford and Hecky 2000; Smith 2006). A water quality database developed for 20 Mediterranean coastal lagoons exhibiting a wide range of external nutrient loading provided the basis for a comparative assessment of nutrient limitation and the controls of algal biomass along this eutrophication gradient, using both the marine (dissolved inorganic nutrients) and the limnological approach (total forms of $\mathrm{N}$ and $\mathrm{P}$ ).

\section{Materials and Methods}

\section{Studied sites}

A database was developed during 1998-2002 for 18 lagoons in the Languedoc-Roussillon (LR) Region of France and 2 lagoons in Corsica (Fig. 1). All marine water bodies (median salinity in summer $>20 \mathrm{psu}$ ) presenting an annually persistent water volume of $\geq 0.5 \times 10^{6} \mathrm{~m}^{3}$ were included in the database (Table 1). Some lagoons were divided into sectors corresponding to hydrodynamic boxes empirically defined on the basis of their bottom contours and depth. The aim was to individualize sectors belonging to the same lagoon but displaying significant differences (see BS, BM and BN in Bages lagoon, Fig. 1). Depending on the lagoon size and shape, 1 to 3 stations (Stns) were located in the middle of each sector.

Salses-Leucate (L), the second largest LR lagoon after Thau (T), has permanent karstic water inputs (Boutière et al. 1982). La Palme lagoon (LP) also features a karstic watershed but its inputs from karst aquifers are weaker than at L (Wilke and Boutière 2000). The BagesSigean (B) lagoon is made up of several smaller basins and has only one opening to the sea at the southernmost end (Jacques et al. 1975). Ayrolle (AY) is directly connected to the sea 
while Gruissan (GR) is connected to the sea by a $2.5 \mathrm{~km}$ channel that can receive freshwater from a diversion canal. Vendres (VE) is a complex wetland-like system whose hydraulic management is made difficult by marine water inflows and the Aude river flash floods (Aloisi and Gadel 1992).

The Thau (T) lagoon is the largest and deepest LR lagoon (Souchu et al. 2001). The digging of the Sète to Rhone canal has split in half 4 lagoons located to the east of T (Ingril to Méjean/Grec). These 8 lagoons are called “palavasian” due to their proximity to the coastal resort of Palavas-les-Flots. Lagoons located landward (Ingril North: IN, Vic: VC, Arnel: AR, Mauguio: M) are bordered by wetlands and can communicate with seafront lagoons (Ingril South: IS, Pierre Blanche: PB, Prévost: PR, Grec: GE) through numerous openings into the Sète to Rhone canal. Or (O), is bordered by a wetland with a steady supply of freshwater from the northeast. The Ponant (PO) lagoon receives freshwater inflow all year round. The small Médard (MD) lagoon is an old feed pond for salt marshes. The 2 Corsican lagoons Diana (D) and Urbino (U), which have a maximum depth of $10 \mathrm{~m}$ and mean depth $\geq 4 \mathrm{~m}$, could be classified as “deep lagoons” as well as T (Frisoni et al. 1983).

Field observations also allowed us to assign to each lagoon a trophic status (Figure 1) according to their phanerogam-macroalgae and/or phytoplankton succession (Duarte 1995, Schramm 1999). The oligotrophic lagoons corresponded to transparent waters with a dominance of marine phanerogams with associated macroalgae. The mesotrophic lagoons included climax species but also proliferating macroalgae. The eutrophic lagoons exhibited a disappearance of Phanerogams, but proliferating macroalgae could still develop. The hypertrophic lagoons exhibited quasi-exclusive dominance by phytoplankton.

\section{Data collection}

This study was focused on the summer period during which primary production is maximum. The 29 Stns (Table 1) were sampled in June, July and August 1999, 2001 and 
2002 except for 10 Stns in 1999 and 4 Stns in 2001. Periods of temporary sediment resuspension were avoided by not sampling for three days following any period of wind speed exceeding $25 \mathrm{~m} \bullet \mathrm{s}^{-1}$. Temperature and salinity were measured with a WTW LF 197 field sensor (precision \pm 0.5\%) calibrated monthly with salinity standards (IAPSO 38H5 Ocean

Scientific). Subsurface water samples were taken by boat between 10 AM and 4 PM with 2

136 liter polypropylene bottles pre-washed with $1 \mathrm{~N}$ acid and then copiously rinsed with deionized 137 water.

138 In the laboratory, water was pre-filtered less than 3 hours after sampling through $200 \mu \mathrm{m}$ 139 mesh to remove most zooplankton. The pre-filtered water was transferred to ashed $\left(450{ }^{\circ} \mathrm{C}\right.$ 140 for 6 h) Pyrex bottles and stored at $-20^{\circ} \mathrm{C}$ for further analyses of total nitrogen (TN) and total 141 phosphorus (TP, see below). For analyses of dissolved inorganic nutrients, the pre-filtered 142 water was filtered through Whatman GF/F membranes with an all-glass filtering system and a 143 vacuum of less than $10 \mathrm{~cm} \mathrm{Hg}$. The whole apparatus and the membrane were pre-rinsed twice 144 before filtration. Ammonium concentrations $\left(\mathrm{NH}_{4}{ }^{+}\right)$were measured according to the manual 145 method of indophenol blue (Aminot and Kérouel 2004). Nitrate $\left(\mathrm{NO}_{3}{ }^{-}\right)$, nitrite $\left(\mathrm{NO}_{2}{ }^{-}\right)$and 146 dissolved inorganic phosphorus (DIP) samples were frozen at $-20{ }^{\circ} \mathrm{C}$ in Pyrex bottles before 147 their analyses on a segmented flow analyzer (Tréguer and Le Corre 1975). Dissolved 148 inorganic nitrogen concentration was expressed as DIN $=\mathrm{NH}_{4}{ }^{+}+\mathrm{NO}_{3}{ }^{-}+\mathrm{NO}_{2}{ }^{-}$. Samples for 149 dissolved silicate analysis (DSi) were stored at $4{ }^{\circ} \mathrm{C}$ in polycarbonate bottles and analysed on 150 a segmented flow analyzer according to Tréguer and Le Corre (1975) in the following weeks. 151 DSi was analyzed only during annual cycles. Although the filtration of water through 152 Whatman GF/F membranes and with an all-glass filtering system potentially could lead to 153 overestimates of DSi, the similarity of these results to those obtained from 2003 to 2006 using 154 nitrate cellulose filter filtration and an all-polycarbonate filtering system leads us to believe 155 that our glass-filtered DSi data are valid. 
Concentrations of TN were measured on the pre-filtered water by chemical oxidation with

157

158

159

160

161

162

163

164

165

166

167

168

169

170

171

172

173

174

175

176

177

178

179

180

potassium persulfate in hot alkaline medium in Teflon vials (adapted from Raimbault and Slawyk 1991). $5 \mathrm{~mL}$ of reagent mix was added to $40 \mathrm{~mL}$ of sample then autoclaved in Teflon vials at $120{ }^{\circ} \mathrm{C}$ ( 1 bar) for $1 \mathrm{~h}$. The various $\mathrm{N}$ forms (except $\mathrm{N}_{2}$ ) were oxidized to nitrate that was then measured according to Tréguer and Le Corre (1975). For analyses of TP, the potassium persulfate oxidation was carried out in acid medium according to Menzel and Corwin (1965). DIP concentrations were then measured according to Tréguer and Le Corre (1975). Measurements of TP in Corsican lagoons were limited to the summer of 2002 due to the use of faulty vials during annual cycle sampling. However, results of TP measurements in 2002 were confirmed by those obtained between 2003 and 2006 (Laugier et al. unpublished).

Chlorophyll $a$ concentrations (Chl-a), described in Bec et al. (unpublished data), were analyzed on all samples. Upon return to the laboratory, 5 to $50 \mathrm{~mL}$ (depending on the phytoplankton abundance) were filtered under a vacuum $<10 \mathrm{~cm} \mathrm{Hg}$ on Whatman GF/F membranes and stored at $-20{ }^{\circ} \mathrm{C}$ in glass tubes. Filters were ground in acetone (90\%) and extracted during $24 \mathrm{~h}$ in the dark at $4{ }^{\circ} \mathrm{C}$. Pigments were measured by spectrofluorimetry (Neveux and Lantoine 1993) and are expressed in $\mu \mathrm{g} \cdot \mathrm{L}^{-1}$ (precision $\pm 5 \%$ ).

Median values for the above water quality parameters were calculated for the pooled data from each lagoon, or from each individual sector of lagoons within which the sector median water quality was found to differ significantly (Kruskal-Wallis, $\mathrm{p}<0.05$ ). Individual sectors were then kept for B and M lagoons whose between-Stn differences were significant for both TN and TP.

\section{Results}

All DIN concentrations were close to $1 \mu \mathrm{mol} \bullet \mathrm{L}^{-1}$ except for lagoons GE and MD (Fig. 2), and the contribution of DIN to TN remained below 6\% except at D. DIP concentrations ranged from low values of $\leq 0.12 \mu \mathrm{mol} \cdot \mathrm{L}^{-1}$ in oligotrophic lagoons $\mathrm{L}, \mathrm{LP}, \mathrm{BS}, \mathrm{AY}, \mathrm{D}$ and $\mathrm{U}$ to 
181 much higher values of $>1 \mu \mathrm{mol} \cdot \mathrm{L}^{-1}$ in hypertrophic lagoons VE and MW (Figure 2). The 182 contribution of DIP to TP remained below 15\% except at BM, BN, T and PO. DSi ranged 183 between $0.5 \mu \mathrm{mol} \cdot \mathrm{L}^{-1}$ at $\mathrm{D}$ and $204 \mu \mathrm{mol} \cdot \mathrm{L}^{-1}$ at $\mathrm{VE}$. DSi individual concentrations remained $184<2 \mu \mathrm{mol} \cdot \mathrm{L}^{-1}$ in $11 \%$ of samples (16 out of 144 samples). Reflecting the strong eutrophication 185 gradient in these lagoons, TN varied from $16 \mu \mathrm{mol} \cdot \mathrm{L}^{-1}$ at $\mathrm{D}$ to $452 \mu \mathrm{mol} \cdot \mathrm{L}^{-1}$ at $\mathrm{VE}$, whereas $186 \mathrm{TP}$ varied from $0.14 \mu \mathrm{mol} \cdot \mathrm{L}^{-1}$ at $\mathrm{D}$ to $28 \mu \mathrm{mol} \cdot \mathrm{L}^{-1}$ at VE. Salinity ranged from $21.3 \mathrm{psu}$ at $\mathrm{O}$ 187 to a maximum value of 40.1 psu at PB. DIP, TN and TP were inversely correlated with 188 salinity (Table 2: Eq. 1 to 5).

189 DIN:DIP ratios varied from 1.1 by moles at VE and PO, to 40 at D. No significant 190 correlation was found between the DIN:DIP ratio and DIN; the observed variability in 191 DIN:DIP instead was largely explained by variations in DIP (Table 2: Eq. 9 and 10; Fig. 2). 192 DIN:DIP was inversely correlated with both TN and TP (Table 2: Eq. 12 and 13). Similarly, 193 DIN:DIP was inversely correlated with DSi (Table 2: Eq. 11), reflecting the almost significant 194 correlation between DIP and DSi (Table 2: Eq. 7). DSi:DIN ratios ranged from 0.5 at D to 195267 at VC, but D was the only lagoon with a DSi:DIN ratio <1. DSi:DIP ratios ranged from $196 \quad 17$ at $\mathrm{BM}$ to 1640 at $\mathrm{L}$.

197 A strong positive relationship was found between TN and TP (Table 2, Eq. 14). TN:TP 198 ratios decreased from about 75 in the less eutrophic lagoons ( $\mathrm{TP}<0.80 \mu \mathrm{mol} \cdot \mathrm{L}^{-1}$ ) to the 199 Redfield ratio (16:1 by moles) in the most eutrophic systems (Fig. 3; Table 2, Eq. 15 and 16). 200 There was also a significant and positive covariance between TN:TP and DIN:DIP (Table 2: 201 Eq. 17; Fig. 4).

202 Chl-a varied along the eutrophication gradient from $<2 \mu g \cdot \mathrm{L}^{-1}$ at $\mathrm{L}, \mathrm{LP}, \mathrm{BS}$ and AY, to $203>270 \mu \mathrm{g} \cdot \mathrm{L}^{-1}$ at VE. There was no significant correlation between DIN and Chl-a (Table 2: Eq. 204 18; Fig. 5). However, both DIP and DSi exhibited weak but significant correlations with Chl-a 205 (Table 2: Eq. 19 and 20; Fig. 5). In contrast, both TN and TP were very strongly correlated 
with Chl-a, with much higher coefficients of determination than for dissolved nutrients (Table

\section{Discussion}

\section{Nutrient limitation assessments using dissolved inorganic nutrients}

Inorganic nutrient concentrations in coastal waters reflect the integrated sum of riverine, sewage, atmospheric, and oceanic inputs, uptake, sorption, grazing, sedimentation, 212 regeneration, burial, etc. (Fisher et al. 1992). We found that summer DIN remained at low 213 concentrations in virtually all lagoons, while DIP and DSi varied largely along a range of concentrations resembling those typically found in coastal and oceanic waters (Nixon 1982; Ragueneau et al. 2002).

When compared to the dissolved nutrient-based criteria for nutrient limitation that have

217 been suggested by Justić et al. (1995),

(1) N limitation: $\mathrm{DIN}<1 \mu \mathrm{mol} \cdot \mathrm{L}^{-1}$; DIN:DIP $<10$; and DSi:DIN $>1$

(2) P limitation: $\quad$ DIP $<0.1 \mu \mathrm{mol} \cdot \mathrm{L}^{-1}$; DIN:DIP $>22$; and DSi:DIP $>22$

(3) Si limitation: $\mathrm{DSi}<2 \mu \mathrm{mol} \cdot \mathrm{L}^{-1}$; DSi:DIN $<1$; and DSi:DIP $<10$

the consistently high DIN:DIP ratios observed in the oligotrophic lagoons (range: 11 to 40 by moles, Fig. 4) suggest that $\mathrm{P}$ was most likely to be the primary limiting nutrient for algal

227 growth in these systems. This conclusion is consistent with the data of Souza et al. (2003) for 228 the oligotrophic Araruama Lagoon (Brazil), as well as the conclusions of Murrell et al. (2006) 229 and Johnson et al. (2006) for several coastal waters in Florida. These general conclusions also 230 are consistent with Downing et al. (1999), who suggested that the role of P in primary 
production limitation in non-polluted coastal waters may have been underestimated. Summer

232 limitation by nitrogen alone seemed to become apparent above a certain level of 233 eutrophication in the studied lagoons (Fig. 4). Experimental nutrient enrichment bioassays 234 carried out in parallel with this study confirmed that both nitrogen and phosphorus limit 235 summer pelagic primary production in the oligotrophic lagoon L (Bec et al. unpublished data), 236 and that nitrogen alone was limiting in the mesotrophic lagoon T (Fouilland et al. 2002).

237 The observed accumulation of DIP along the eutrophication gradient and the inverse 238 correlation between DIP and salinity could be explained by invoking progressively lower N:P 239 supply ratios that reflect an increasing influence of sewage inputs on the total nutrient load 240 (Downing and McCauley 1992). However, nowadays, sewage can be richer in $\mathrm{N}$ than in $\mathrm{P}$ 241 because of a more effective removal of $\mathrm{P}$ as it is the case for the 8 Palavasian and O lagoons 242 (Table 3). Moreover, the range of $\mathrm{N}: \mathrm{P}$ loading ratios to the 13 lagoons for which $\mathrm{N}$ and $\mathrm{P}$ 243 loading data are available is narrower than the ranges of DIN:DIP and TN:TP in the water 244 column. We tentatively conclude that the observed increase of DIP along the eutrophication 245 gradient is better explained by the $\mathrm{P}$ content of lagoon sediments than by salinity, and that 246 recycling processes strongly affect inorganic nutrient concentrations in the water column 247 (Souchu et al. unpublished data).

248 Egge and Aksnes (1992) have shown that diatoms often dominate the phytoplankton 249 community when DSi concentrations exceeded $2 \mu \mathrm{mol} \cdot \mathrm{L}^{-1}$. However, few samples in the 250 pooled database exhibited DSi concentrations $<2 \mu \mathrm{mol} \cdot \mathrm{L}^{-1}(13 \%)$. Moreover, based the 251 empirical criteria in Eq. 1-3 above, the relatively high observed ratios of DSi:DIN (range: 0.5 252 to 267 by moles) and DSi:DIP (range: 17 to 1640 by moles) together suggest that DSi was 253 very unlikely to limit algal growth in the studied lagoons, even at extreme levels of nutrient 254 enrichment. The trend for DSi to accumulate along the eutrophication gradient was 255 unexpected because DSi typically is not increased by any significant extent during 
anthropogenic $\mathrm{N}$ and $\mathrm{P}$ enrichment (Conley et al. 1993). Indeed, several authors have reported

257 a pattern of species shifts towards phytoplankton species other than diatoms as a consequence 258 of DSi depletion in nutrient-enriched waters (Anderson et al. 2002; Turner 2002). However, 259 phytoplanktonic proliferation induces an accumulation in sediments of diatom frustules, 260 whose dissolution can lead to summer DSi maxima (Aller and Benniger 1981). The similarity 261 of DIP and DSi relationships with Chl-a (see below), which suggest the accumulation of both 262 dissolved nutrients along the eutrophication gradient, could potentially result from the 263 recycling of phytoplankton at the water-sediment interface in the studied lagoons (Bec et al., unpublished data; Souchu et al. unpublished data.).

\section{Nutrient limitation assessments using total nutrients}

Guildford and Hecky (2000) proposed the following criteria for N and P limitation assessment in lake and ocean waters, using molar ratios of total nitrogen and total phosphorus (Eq. 4-6):
(4) N limitation:
$\mathrm{TN}: \mathrm{TP}<20$
(5) N and P limitation:
$\mathrm{TN}: \mathrm{TP}=20-50$

(6) P limitation:

$\mathrm{TN}: \mathrm{TP}>50$

Based upon these empirical thresholds, we conclude that the most oligotrophic lagoons in this study were consistently limited by P (Fig. 4). For a majority of the studied lagoons, the phytoplankton production was likely limited by both N and P (TN:TP = 20-50). The three lagoons having TN:TP <20 (VE, MW and PO) were also those for which the median summer DIP concentration was in excess $\left(>1 \mu \mathrm{mol} \bullet \mathrm{L}^{-1}\right.$; see Fig. 2$)$, providing additional evidence that 
$\mathrm{P}$ was unlikely to limit net primary production in these low $\mathrm{N}: \mathrm{P}$ ratio systems. Summer 282 limitation of algal growth by $\mathrm{N}$ thus may only occur in more mesotrophic Mediterranean coastal lagoons, with a tendency towards increasingly likelihood of $\mathrm{N}$-limitation as eutrophication increases; consequently, transitions from limitation by $\mathrm{P}$ to limitation by $\mathrm{N}$ may be considered as an indication of anthropogenic eutrophication in these systems.

The convergence of the limnological and marine approaches in lagoons is evident from the positive and high correlation between DIN:DIP and TN:TP (Table 2, Eq. 17). The relationship suggests that TN:TP $=45$ when DIP:DIN is 16 , a value that is close to the empirical TN:TP threshold proposed by Guilford and Hecky (2000). However, if the decrease of DIN:DIP along the eutrophication gradient (Table 2, Eq. 13) is clearly due to DIP accumulation, the TN:TP ratio decrease (Table 2, Eq. 16) is more difficult to explain since TN and TP are a mixture of inorganic nutrients, dissolved organic matter (DOM) and seston. In the study lagoons, regarding to the low contribution of inorganic nutrients to TN and TP (ca. $10 \%), \mathrm{TN}$ and TP can be considered as essentially made of seston and DOM. The N:P ratios in DOM are largely higher than Redfield ratio (Hopkinson and Vallino 2005) while TN:TP ratios in sestonic organic matter would display values closer to the Redfield ratio (Hall et al. 2005). As Chl-a concentrations increase, TN and TP are increasingly determined by the $\mathrm{N}$ and P content of the phytoplankton cells (see Wetzel 2001 for DON and PON in lakes). This trend may help to explain why TN:TP ratios move closer to the Redfield ratio as eutrophication increases (Fig. 3). In hypertrophic lagoons (VE in Fig. 3), the planktonic biomass is high enough that TN:TP ratios are close to 16.

\section{Nutrient controls of algal biomass}

The predictive power of using a total nutrient-based approach for the prediction of summer median algal biomass is strongly evident in the lagoons studied here: total $\mathrm{N}$ and total P-based regression models for summer median Chl-a were consistently much superior to 
comparable DIN- and DIP-based models (compare Figs. 5 and 6). There was in fact no correlation between concentrations of DIN and Chl-a (Table 2: Eq. 18), and both DIP and DSi exhibited only weak correlations with Chl-a (Table 2: Eq. 19 and 20). It is also very important to note that the simple regression model reported here for summer median TP and Chl-a in coastal Mediterranean lagoons

(7) $\quad \log$ Chl-a $=0.690+1.08 \log \mathrm{TP}, \mathrm{r}^{2}=0.78$

confirms the strongly positive relationship observed by Knoppers et al. (1991; data not shown) for annual average TP and Chl-a in six coastal lagoons in Brazil:

as well as that observed between annual median TP and summer median Chl-a in 15 coastal embayments in Germany (Sagert et al. 2008, data not shown):

(9) $\quad \log$ Chl-a $=0.601+1.24 \log \mathrm{TP}, \mathrm{r}^{2}=0.83$.

A similarly strong relationship has been found between summer mean concentrations of TP and Chl-a in the hypertrophic Vistonis Lagoon, Greece (Gikas et al. 2006; data not shown):

(10) $\log$ Chl-a $=0.300+2.367 \log \mathrm{TP}, \mathrm{r}^{2}=0.92$, 
Moreover, Boynton et al. (1996) found significant relationships between annual TN loading rates and average TN and Chl-a concentrations for Maryland coastal bays, even without making any adjustments for hydraulic residence time. We found very significant relationships between annual total $\mathrm{N}$ and $\mathrm{P}$ loading rates and median $\mathrm{TN}$ and $\mathrm{TP}$ concentrations for the 13 lagoons with well-defined watersheds (Table 3), without making any 336 adjustments for their hydraulic residence time $\left(\mathrm{r}^{2}=0.85\right.$ and 0.94 for $\mathrm{N}$ and $\mathrm{P}$ respectively, 337 ANOVA p < 0.05; Dupré unpublished data). Søballe and Kimmel (1987) have suggested that 338 algal production per unit $\mathrm{P}$ in water increases in the sequence: rivers $<$ impoundments $<$ natural 339 lakes, and suggested that we view aquatic systems as occupying positions along a continuum 340 ordered by water residence time. The Mediterranean lagoons studied here appear to behave 341 very similarly to lakes because they have relatively long hydraulic residence times due to their 342 low tidal amplitudes (Bacher et al. 1995).

\section{Implications for eutrophication management}

344 As noted by Rabalais et al. (2009), coastal water quality is currently on the decline, and 345 excessive exports of nutrients from the land to the world's coastal oceans will almost certainly 346 continue to occur unless societal intervention or changes in human culture are successfully 347 pursued. Our cross-system comparison of Chl-a and nutrients from 20 coastal Mediterranean 348 lagoons suggests that the identity of the primary limiting growth-limiting nutrient in these 349 systems may shift from $\mathrm{P}$ alone in oligotrophic lagoons, to $\mathrm{N}$ alone as eutrophication 350 proceeds. We tentatively conclude that, like most unenriched freshwater systems, pristine 351 coastal French Mediterranean lagoons may typically be P-limited.

352 A critical need remains for water resource managers to reduce nutrient loads, in order to 353 reduce the negative effects of global eutrophication and to prevent further degradation 354 (Rabalais et al. 2009). The management of eutrophication will require careful assessments of 355 whether $\mathrm{N}, \mathrm{P}$, or both $\mathrm{N}$ and $\mathrm{P}$ should be controlled in order to develop successful and cost- 
effective strategies for the control of coastal zone eutrophication. We note, however, that

357 Elser et al. (2007) found that while enrichment by either $\mathrm{N}$ or $\mathrm{P}$ can increase autotroph 358 production, a simultaneous increase in both nutrients leads to dramatically higher levels of 359 production in nearly all situations. We surmise that the converse response also can be 360 expected to occur (i.e., simultaneous reductions in both $\mathrm{N}$ and $\mathrm{P}$ will minimize algal 361 production), and we thus favor joint $\mathrm{N}$ and $\mathrm{P}$ loading control to protect estuarine and coastal 362 marine environments. However, such management decisions will need to be based upon 363 careful syntheses of current and historical data (e.g., Conley et al. 2009; Paerl 2009), as well 364 as quantitative and objective frameworks for the assessment of coastal zone water quality.

365 Strong relationships between Chl-a and total nutrient, and empirical models predicting in366 lake P concentrations as a function of annual P load have been essential tools for management 367 of eutrophication in lakes for more than three decades (Vollenweider 1976; OECD 1982). We 368 concur with Hoyer et al. (2002) that an approach using total nutrients is similarly valid for 369 eutrophication modeling in marine systems, and as shown by the data presented here, it is in 370 fact superior to approaches that rely upon concentrations and ratios of dissolved inorganic 371 nutrients. However, Cloern (2001) has suggested that differences between the eutrophication 372 response of lakes and coastal waters to eutrophication potentially may result from system373 specific attributes that act as filters that may modulate their respective responses to enrichment. We thus urge other researchers worldwide to test the utility of this empirical 375 approach in coastal waters that exhibit a wide range of physicochemical, biological, and 376 hydrological characteristics in order to confirm if the tools and methods that have been so 377 very successful in the management of freshwater eutrophication, are also broadly applicable 378 to coastal marine ecosystems.

\section{Acknowledgments}


381 Suivi Lagunaire) financed by Agence de l'Eau, Région Languedoc-Roussillon and Ifremer. 382 This paper also was supported in part by NSF DMS-0342239 to Val H. Smith. We thank the 383 staff of the Ifremer laboratories in Corsica and Languedoc-Roussillon, the Parc Naturel 384 Régional de la Narbonnaise. The authors are grateful to anonymous reviewers for their 385 comments on the paper. This paper is dedicated to Nicolas Dupré (1978-2008). 


\section{References}

387 Aller, R.C., and Benninger, L.K. 1981. Spatial and temporal patterns of dissolved ammonium, manganese and silica fluxes from bottom sediments in Long Island Sound U.S.A. J. Mar. Res. 39: 295-314.

Aloisi, J.C., and Gadel, F. 1992. Mécanismes sédimento-génétiques et évolution d’un écosystème lagunaire Méditerranéen: L’étang de Vendres (Hérault). Vie Milieu, 42: 165183.

Aminot, A., and Kérouel, R. 2004. Hydrologie des écosystèmes marins. Paramètres et analyses. Ifremer, Brest, France.

Anderson, D.M., Glibert, P.M., and Burkholder, J.M. 2002. Harmful algal blooms and eutrophication: nutrient sources, composition, and consequences. Estuaries, 25: 704-726.

Bacher, C., Bioteau, H., and Chapelle, A. 1995. Modelling the impact of a cultivated oyster population on the nitrogen dynamics: the Thau lagoon case (France). Ophelia, 42: 29-54.

Boutière, H., de Bovée, F., Delille, D., Fiala, M., Gros, C., Jacques, G., Knoepffler, M., Labat, J.P., Panouse, M., and Soyer, J. 1982. Effet d'une crise dystrophique dans l'étang de Salses-Leucate. Proceedings International Symposium on coastal lagoons. SCOR/IABO/UNESCO, Bordeaux, 8-14 September, Oceanol. Acta, pp. 231-242.

Boynton, W.R., Murray, L., Hagy, J.D., Stokes, C., and Kemp, W.M. 1996. A comparative analysis of eutrophication patterns in a temperate coastal lagoon. Estuaries, 19: 408-421.

Champion, M., and Currie, D.J. 2000. Phosphorus-chlorophyll relationships in lakes, rivers, and estuaries. Verh. Int. Ver. Theor. Angew. Limnol. 27: 1986-1989.

Cloern, J.E. 2001. Our evolving conceptual model of the coastal eutrophication problem. Mar. Ecol. Prog. Ser. 210: 223-253. 
Conley, D.J., Paerl, H.W., Howarth, R.W., Boesch, D.F., Seitzinger, S.P., Havens, K.E. Lancelot, C., and Likens, G.E. 2009. Controlling eutrophication: nitrogen and phosphorus. Science, 323: 1014-1015.

Conley, D.J., Schelske, C.L., and Stoermer, E.F. 1993. Modification of the biogeochemical cycle of silica with eutrophication. Mar. Ecol. Prog. Ser. 101: 179-192.

Dodds, W.K. 2003. Misuse of inorganic N and soluble reactive P concentrations to indicate nutrient status of surface waters. J. N. Am. Benthol. Soc. 22: 171-181.

Downing, J.A. 1997. Marine nitrogen:phosphorus stoichiometry and the global N:P cycle. Biogeochemistry, 37: 237-252.

Downing, J.A., and McCauley, E. 1992. The nitrogen:phosphorus relationship in lakes. Limnol. Oceanogr. 37: 936-945.

Downing, J.A., Osenberg, C.W., and Sarnelle, O. 1999. Meta-analysis of marine nutrientenrichments: Variations in the magnitude of nutrient limitation. Ecology, 80: 1157-1167.

Duarte, C.M. 1995. Submerged aquatic vegetation in relation to different nutrient regimes. Ophelia, 41: 87-112.

EAA. 1999. State and pressures of the marine and coastal Mediterranean environment. European Environment Agency, Copenhagen.

EEC. 2000. Council Directive for a legislative frame and actions for the water policy, 2000/60/EC. Official Journal of the European Community, 22/12/2000.

Egge, J.K., and Aksnes, D.L. 1992. Silicate as regulating nutrient in phytoplankton competition. Mar. Ecol. Prog. Ser. 83: 281-289.

Elser, J.J., Bracken, M.E.S., Cleland, E.E., Gruner, D.S., Harpole, W.S., Hillebrand, H., Ngai J.T., Seabloom, E.W., Shurin, J.B., and Smith, J.E. 2007. Global analysis of nitrogen and phosphorus limitation of primary producers in freshwater, marine and terrestrial ecosystems. Ecol. Lett. 10: 1135-1142. 
Elser, J.J., Marzolf, E.R. and Goldman, C.R. 1990. Phosphorus and nitrogen limitation of phytoplankton growth in the freshwaters of North America: a review and critique of experimental enrichments. Can. J. Fish. Aquat. Sci. 47: 1468-1477

Fisher, T.R., Melack, J.M., Grobbelaar, J.U., and Howarth, R.W. 1995. Nutrient limitation of phytoplankton and eutrophication of inland, estuarine, and marine waters. In Phosphorus in the global environment: Transfers, cycles and management. Edited by H. Tiessen. Wiley and Sons, New York, NY, pp. 301-322.

Fisher, T.R., Peele, E.R., Ammerman, J.W. and Harding, L.W. Jr. 1992. Nutrient limitation of phytoplankton in Chesapeake Bay. Mar. Ecol. Prog. Ser. 82: 51-63.

Fouilland, E., Descolas-Gros, C., Collos, Y., Vaquer, A., Souchu, P., Gasc, A., Bibent, B., and Pons, V. 2002. Influence of nitrogen enrichment on size-fractionated in vitro carboxylase activities of phytoplankton from Thau lagoon (Coastal Mediterranean Lagoon, France). J. Exp. Mar. Biol. Ecol. 275: 147-171.

Frisoni, G.F., Guelorget, O., Ximenes, M.C., and Perthuisot, J.P. 1983. Etude écologique de trois lagunes de la plaine orientale Corse (Biguglia, Diana, Urbino): Expressions biologiques qualitatives et quantitatives du confinement. J. Rech. Oceanogr. 8: 57-80.

Gikas, G.D., Yiannakopoulou, T., and Tsihrintzis, V.A. 2006. Water quality trends in a coastal lagoon impacted by non-point source pollution after implementation of protective measures. Hydrobiologia, 563: 385-406.

Guildford, S.J., and Hecky, R.E. 2000. Total nitrogen, total phosphorus, and nutrient limitation in lakes and oceans: Is there a common relationship? Limnol. Oceanogr. 45: $1213-1223$.

Hall, S.R., Smith, V.H., Lytle, D.A., and Leibold, M.A. 2005. Constraints on primary producer N:P stoichiometry along N:P supply ratio gradients. Ecology, 86: 1894-1904.

Hopkinson, C.S., and Vallino, J.J. 2005. Efficient export of carbon to the deep ocean through dissolved organic matter. Nature, 433: 142-145. 
Hoyer, M.V., Frazer, T.K., Notestein, S.K., and Canfield, D.E., Jr. 2002. Nutrient, chlorophyll, and water clarity relationships in Florida's nearshore coastal waters with comparisons to freshwater lakes. Can. J. Fish. Aquat. Sci. 59: 1024-1031.

463

464

465

466

467

468

469

470

471

472

473

474

475

476

477

478

479

480

481

482

Ignatiades, L. 2005. Scaling the trophic status of the Aegean Sea, eastern Mediterranean. J. Sea Res. 54: 51-57.

Jacques, G., Cahet, G., Fiala, M., Neveux, J., and Panouse, M. 1975. Caractéristiques du milieu pélagique des étangs de Bages-Sigean et de Salses-Leucate pendant l'été 1974. Vie Milieu, 25: 1-18.

Johnson, M.W., Heck, K.L., and Fourqurean, J.W. 2006. Nutrient content of seagrasses and epiphytes in the northern Gulf of Mexico: Evidence of phosphorus and nitrogen limitation. Aquat. Bot. 85: 103-111.

Justić, D., Rabalais, N.N., Turner, E., and Dortch, Q. 1995. Changes in nutrient structure of river-dominated coastal waters: stoichiometric nutrient balance and its consequences. Est. Coast. Shelf Sci. 40: 339-356.

Knoppers, B., Kjerfve B., and Carmouze J.-P. 1991. Trophic state and water turn-over time in six choked coastal lagoons in Brazil. Biogeochemistry, 14: 149-166.

Lewis, W.M. Jr., and Wurtsbaugh, W.A. 2008. Control of lacustrine phytoplankton by nutrients: Erosion of the phosphorus paradigm. Internat. Rev. Hydrobiol. 93: 446-465.

Meeuwing, J.J., Kauppila, P., and Pitkänen, H. 2000. predicting coastal eutrophication in the Baltic: a limnological approach. Can. J. Fish. Aquat. Sci. 57: 844-855.

Menzel D.W., and Corwin N. 1965. The measurement of total phosphorus in seawater based on the liberation of organically bound fractions by persulfate oxidation. Limnol. Oceanogr. 10: $280-282$. 
Murrell, M.C., Stanley, R.S., Lores, E.M., DiDonato, G.T., Smith, L.M., and Flemer, D.A. 2006. Evidence that phosphorus limits phytoplankton growth in a Gulf of Mexico estuary: Pensacola Bay, Florida, USA. Bull. Mar. Sci. 70: 155-167.

Neveux, J., and Lantoine, F. 1993. Spectrofluorimetric assay of chlorophylls and phaepigments using the least squares approximation technique. Deep-Sea Res. 40: 17471765.

Nixon, S.W. 1982. Nutrient dynamics, primary production and fisheries yields of lagoons. Proceedings International Symposium on coastal lagoons SCOR/IABO/UNESCO, Bordeaux, 8-14 September, Oceanol Acta, pp. 357-371.

Nixon, S.W. 1995. Coastal marine eutrophication: A definition, social causes, and future concerns. Ophelia, 41: 199-219.

Organisation for Economic Cooperation and Development (OECD). 1982. Eutrophication of waters: monitoring, assessment and control. Organisation for Economic Cooperation and Development OECD, Paris.

Paerl, H.W. 2009. Controlling eutrophication along the freshwater-marine continuum: Dual nutrient ( $\mathrm{N}$ and $\mathrm{P}$ ) reductions are essential. Estuar. Coasts, 32: 593-601.

Prairie, Y.T., Duarte, C.M., and Kalff, J. 1989. Unifying nutrient-chlorophyll relationships in lakes. Can. J. Fish. Aquat. Sci. 46: 1176-1182.

Rabalais, N.N., Turner, R.E., Díaz, R.J., and Justić, D. 2009. Global change and eutrophication of coastal waters. ICES J. Mar. Sci. 66: 1528-1537.

Ragueneau, O., Lancelot, C., Egorov, V., Vervlimmeren, J., Cociasu, A., Déliat, G., Krastev, A., Daoud, N., Rousseau, V., Popovitchev, V., Brion, N., Popa, L., and Cauwet, G. 2002. Biogeochemical transformations in inorganic nutrients in the mixing zone between the Danube River and the North-western Black Sea. Estuar. Coast Shelf Sci. 54: 321-336. 
507 Raimbault, P., and Slawik, G. 1991. A semiautomatic, wet-oxidation method for the 508 determination of particulate organic nitrogen collected on filters. Limnol. Oceanogr. 36: $509 \quad 405-408$.

510 Ryther J.H., Dunstan W.H. 1971. Nitrogen, phosphorus, and eutrophication in the coastal 511 marine environment. Science, 171: 1008-1013.

512 Sagert, S., Rieling, T., Eggert, A., and Schubert H. 2008. Development of a phytoplankton 513 indicator system for the ecological assessment of brackish coastal waters (German Baltic $514 \quad$ Sea coast). Hydrobiologia, 611: 91-103.

515 Schindler, D.W. 1977. Evolution of phosphorus limitation in lakes. Science, 195: 260-262.

516 Schramm, W. 1999. Factors influencing seaweed responses to eutrophication: some results 517 from EU-project EUMAC. J. Appl. Phycol. 11: 69-78.

518 Smith, V.H. 2003. Eutrophication of freshwater and marine ecosystems: A global problem. 519 Environ. Sci. Pollut. Res. 10: 126-139.

520 Smith, V.H. 2006. Responses of estuarine and coastal marine phytoplankton to nitrogen and 521 phosphorus enrichment. Limnol. Oceanogr. 51: 377-384.

522 Søballe, D.M., and Kimmel, B.L. 1987. A large-scale comparison of factors influencing 523 phytoplankton abundance in rivers, lakes and impoundments. Ecology, 68: 1943-1954.

524 Souchu, P., Vaquer, A., Collos, Y., Landrein, S., Deslous-Paoli, J.-M., and Bibent, B. 2001. 525 Influence of shellfish farming activities on the biogeochemical composition of the water 526 column in Thau lagoon. Mar. Ecol. Prog. Ser. 218: 141-152.

527 Souza, M.F.L., Kjerfve, B., Knoppers, B., Landim de Souza, W.F., and Damasceno, R.N. 528 2003. Nutrient budgets and trophic states in a hypersaline coastal lagoon: Lagoa de 529 Araruama, Brazil. Est. Coast. Shelf Sci. 57: 843-858.

530 Tréguer, P., and Le Corre, P. 1975. Manuel d'analyse des sels nutritifs dans l'eau de mer. 531 Utilisation de l'auto analyseur II, Technicon. L.O.C. Univ. Bretagne Occidentale, Brest, Fr. 
532 Turner, R.E. 2002. Element ratios and aquatic food webs. Estuaries, 25: 694-703.

533 Vollenweider, R.A. 1976. Advances in defining critical loading levels of phosphorus in lake 534 eutrophication. Mem. Ist. Ital. Idrobiol. 33: 53-83.

535 Wetzel, R.G. 2001. Limnology: lake and river ecosystems. Academic Press, San Diego, Ca.

536 Wilke, M., and Boutière, H. 2000. Hydrobiological, physical and chemical characteristics and 537 spatio-temporal dynamics of an oligotrophic mediterranean lagoon: The étang de La Palme 538 (France). Vie Milieu, 50: 101-115.

539 
539 Table 1. Summary characteristics of the 20 studied lagoons.

\begin{tabular}{|c|c|c|c|c|c|c|}
\hline Lagoon & Label & $\begin{array}{l}\text { Mean } \\
\text { depth }\end{array}$ & Area & Volume & Station & $\begin{array}{c}\text { Station } \\
\text { Depth }\end{array}$ \\
\hline \multirow{3}{*}{ Salse-Leucate } & & $(\mathrm{m})$ & $\left(\mathrm{km}^{2}\right)$ & $\left(\times 10^{6} \mathrm{~m}^{3}\right)$ & & $(\mathrm{m})$ \\
\hline & \multirow{2}{*}{$\mathbf{L}$} & \multirow{2}{*}{2.0} & \multirow{2}{*}{54} & \multirow{2}{*}{90} & LS & 3.0 \\
\hline & & & & & $\mathbf{L N}$ & 2.6 \\
\hline \multirow[t]{2}{*}{ La Palme } & \multirow[t]{2}{*}{$\mathbf{L P}$} & \multirow[t]{2}{*}{0.5} & \multirow[t]{2}{*}{6.0} & \multirow[t]{2}{*}{3.3} & LP & 1.5 \\
\hline & & & & & BS & 1.3 \\
\hline \multirow[t]{2}{*}{ Bages-Sigean } & \multirow[t]{2}{*}{ B } & \multirow[t]{2}{*}{1.3} & \multirow[t]{2}{*}{37} & \multirow[t]{2}{*}{49} & BM & 2.0 \\
\hline & & & & & BN & 2.1 \\
\hline Ayrolle & $\mathbf{A Y}$ & 0.5 & 13.2 & 9.0 & AY & 0.9 \\
\hline Gruissan & GR & 0.5 & 1.4 & 1.0 & GR & 0.7 \\
\hline Vendres & VE & 0.9 & $4.8 / 10$ & $1.4 / 3.0$ & VE & 0.8 \\
\hline \multirow{2}{*}{ Thau } & \multirow{2}{*}{$\mathbf{T}$} & \multirow{2}{*}{4.0} & \multirow{2}{*}{75} & \multirow{2}{*}{260} & TW & 5.5 \\
\hline & & & & & TE & 9.0 \\
\hline \multicolumn{7}{|l|}{ Palavasian } \\
\hline South-Ingril & IS & 0.6 & 3.6 & 2.2 & IS & 1.0 \\
\hline North-Ingril & IN & 0.6 & 3.2 & 1.9 & IN & 1.0 \\
\hline Pierre-Blanche & PB & 0.4 & 3.7 & 1.5 & PB & 0.9 \\
\hline Vic & VC & 1.2 & 11.5 & 13.8 & VC & 1.6 \\
\hline \multirow{2}{*}{ Prévost } & \multirow{2}{*}{ PR } & \multirow{2}{*}{0.75} & \multirow{2}{*}{3.8} & \multirow{2}{*}{2.9} & PRW & 0.8 \\
\hline & & & & & PRE & 0.9 \\
\hline Arnel & $\mathbf{A R}$ & 0.40 & 4.7 & 1.9 & AR & 0.7 \\
\hline Grec & GE & 0.30 & 2.7 & 0.7 & GE & 0.7 \\
\hline \multirow{2}{*}{ Méjean } & \multirow{2}{*}{$\mathbf{M}$} & \multirow{2}{*}{0.75} & 5 & 41 & MW & 0.8 \\
\hline & & & & & ME & 0.9 \\
\hline Or (Mauguio) & $\mathbf{O}$ & 0.8 & 32 & 24 & ow & 1.2 \\
\hline & & & & & OE & 1.2 \\
\hline Ponant & PO & 2.7 & 2.0 & 5.4 & PO & 3.5 \\
\hline Médard & MD & 0.6 & 1.4 & 0.9 & MD & 0.8 \\
\hline Corsican & & & & & & \\
\hline Diana & D & 6.0 & 5.7 & 10.2 & DS & 8.0 \\
\hline & & & & & DN & 7.0 \\
\hline Urbino & $\mathbf{U}$ & 5.0 & 7.6 & 33 & US & 7.5 \\
\hline & & & & & UN & 7.5 \\
\hline
\end{tabular}


540 Table 2. Empirical models and summary statistics for the relationships between salinity,

541 nutrients and Chl-a in the 20 studied lagoons. n: sample size; $\mathrm{r}^{2}$ : coefficient of determination;

542 p: significance level of $r$; NS: not significant ( $p \geq 0.05)$.

\begin{tabular}{|c|c|c|c|c|}
\hline Equation & Regression Model & $\mathbf{n}$ & $\mathbf{r}^{2}$ & $\mathbf{p}$ \\
\hline 1 & $\log _{10} \mathrm{DIN}$ on $\log _{10} \mathrm{Sal}$ & 23 & NS & 0.29 \\
\hline 2 & $\log _{10} \mathrm{DIP}=4.8-3.7 \log _{10} \mathrm{Sal}$ & 23 & 0.39 & 0.001 \\
\hline 3 & $\log _{10} \mathrm{DSi}=5.8-3.1 \log _{10} \mathrm{Sal}$ & 23 & NS & 0.12 \\
\hline 4 & $\log _{10} \mathrm{TN}=5.3-2.3 \log _{10} \mathrm{Sal}$ & 23 & 0.25 & 0.01 \\
\hline 5 & $\log _{10} \mathrm{TP}=5.8-3.7 \log _{10} \mathrm{Sal}$ & 23 & 0.30 & 0.006 \\
\hline 6 & $\log _{10} \mathrm{DIN}$ on $\log _{10} \mathrm{DIP}$ & 23 & NS & 0.08 \\
\hline 7 & $\log _{10} \mathrm{DIN}$ on $\log _{10} \mathrm{DSi}$ & 23 & NS & 0.38 \\
\hline 8 & $\log _{10} \mathrm{DSi}$ on $\log _{10} \mathrm{DIP}$ & 23 & NS & 0.05 \\
\hline 9 & $\log _{10} \mathrm{DIN}: \mathrm{DIP}$ on $\log _{10} \mathrm{DIN}$ & 23 & NS & 0.56 \\
\hline 10 & $\log _{10} \mathrm{DIN}: \mathrm{DIP}=0.30-0.69 \log _{10} \mathrm{DIP}$ & 23 & 0.76 & 0.0001 \\
\hline 11 & $\log _{10} \mathrm{DIN}: \mathrm{DIP}=1.24-0.34 \log _{10} \mathrm{DSi}$ & 23 & 0.19 & 0.04 \\
\hline 12 & $\log _{10} \mathrm{DIN}: \mathrm{DIP}=1.67-0.47 \log _{10} \mathrm{TN}$ & 23 & 0.20 & 0.03 \\
\hline 13 & $\log _{10} \mathrm{DIN}: \mathrm{DIP}=0.97-0.45 \log _{10} \mathrm{TP}$ & 23 & 0.34 & 0.003 \\
\hline 14 & $\log _{10} \mathrm{TN}=1.64+0.65 \log _{10} \mathrm{TP}$ & 23 & 0.92 & 0.0001 \\
\hline 15 & $\log _{10} \mathrm{TN}: \mathrm{TP}=2.2-0.37 \log _{10} \mathrm{TN}$ & 23 & 0.52 & 0.0001 \\
\hline 16 & $\log _{10} \mathrm{TN}: \mathrm{TP}=1.63-0.30 \log _{10} \mathrm{TP}$ & 23 & 0.77 & 0.0001 \\
\hline 17 & $\log _{10} \mathrm{TN}: \mathrm{TP}=1.24+0.34 \log _{10} \mathrm{DIN}: \mathrm{DIP}$ & 23 & 0.48 & 0.0003 \\
\hline 18 & $\log _{10}$ Chl-a on $\log _{10}$ DIN & 23 & NS & 0.22 \\
\hline 19 & $\log _{10} \mathrm{Chl}-\mathrm{a}=1.60+0.72 \log _{10} \mathrm{DIP}$ & 23 & 0.27 & 0.001 \\
\hline 20 & $\log _{10} \mathrm{Chl}-\mathrm{a}=-0.23+0.70 \log _{10} \mathrm{DSi}$ & 23 & 0.23 & 0.02 \\
\hline 21 & $\log _{10}$ Chl-a $=-1.96+1.62 \log _{10} \mathrm{TN}$ & 23 & 0.81 & 0.0001 \\
\hline 22 & $\log _{10}$ Chl-a $=0.69+1.08 \log _{10} \mathrm{TP}$ & 23 & 0.78 & 0.0001 \\
\hline
\end{tabular}


543 Table 3. Contribution of sewage to total inputs of $\mathrm{N}$ and $\mathrm{P}$ in 13 lagoons for which the 544 watershed is well defined (Dupré et al., unpublished data). N:P ratios (by moles) in sewage 545 and inputs are compared with ratios in lagoon waters. For Bages (B) and the 8 Palavasian 546 lagoons, N:P ratios in the water correspond to pooled data from all stations.

\begin{tabular}{lcccccc}
\hline \multicolumn{1}{c}{ Lagoons } & \multicolumn{2}{c}{$\begin{array}{c}\text { \% contribution of } \\
\text { sewage to total inputs }\end{array}$} & $\begin{array}{c}\text { TN:TP } \\
\text { in sewage }\end{array}$ & $\begin{array}{c}\text { TN:TP } \\
\text { in total inputs }\end{array}$ & $\begin{array}{c}\text { DIN:DIP } \\
\text { in water }\end{array}$ & $\begin{array}{c}\text { TN:TP } \\
\text { in water }\end{array}$ \\
\hline Bages & N & P & & & & \\
La Palme & 39 & 12 & 26.5 & 33.1 & 4.9 & 41 \\
Leucate & 37 & 14 & 3.4 & 16.0 & 11.4 & 85 \\
Or & 39 & 21 & 8.9 & 16.5 & 36.5 & 46 \\
Palavasian (8) & 49 & 55 & 24.0 & 27.4 & 11.5 & 29 \\
Thau & 34 & 77 & 26.2 & 23.0 & 7.7 & 29 \\
\hline
\end{tabular}




\section{Figure captions}

548 Fig. 1. Location of sampling Stns and limits of sectors (dotted line) in oligotrophic ( $\square$ ),

549 mesotrophic $(\Delta)$, eutrophic $(\boldsymbol{\square})$ and hypertrophic $(\boldsymbol{\Delta})$ LR and Corsica lagoons.

550 Fig. 2. Log scaled plot of DIN on DIP in oligotrophic ( $\square)$, mesotrophic $(\Delta)$, eutrophic $(\square)$

551 and hypertrophic ( $\mathbf{A})$ LR and Corsica lagoons.

552 Fig. 3. Relationship between TN and TP in oligotrophic ( $\square$ ), mesotrophic $(\Delta)$, eutrophic

553 ( $\mathbf{\square})$ and hypertrophic $(\boldsymbol{\Delta})$ LR and Corsica lagoons. The dotted line corresponds to the 554 Redfield ratio (16:1 by moles). See Table 2 for regression parameters.

555 Fig. 4. Relationship between TN:TP and DIN:DIP in oligotrophic ( $\square)$, mesotrophic $(\Delta)$, 556 eutrophic ( $\boldsymbol{\square})$ and hypertrophic ( $\mathbf{\Delta})$ LR and Corsica lagoons. The solid and the dotted lines 557 correspond respectively to the ratios used by Justić et al. (1995) for dissolved inorganic 558 nutrients, and by Guildford and Hecky (2000) for total nutrients, to discriminate phosphorus 559 limitation from nitrogen limitation. See Table 2 for regression equations.

560 Fig. 5. Relationships between Chl-a and DIN, DIP and DSi in oligotrophic ( $\square$ ), mesotrophic

$561(\Delta)$, eutrophic $(\square)$ and hypertrophic $(\boldsymbol{\Delta})$ LR and Corsica lagoons. See Table 2 for 562 regression equations.

563 Fig. 6. Relationships between Chl-a, and TN and TP in oligotrophic ( $\square$ ), mesotrophic $(\Delta)$, 564 eutrophic $(\boldsymbol{\square})$ and hypertrophic $(\boldsymbol{\Delta})$ LR and Corsica lagoons. See Table 2 for regression 565 equations. 


\section{FIGURE 1}

566

567

568

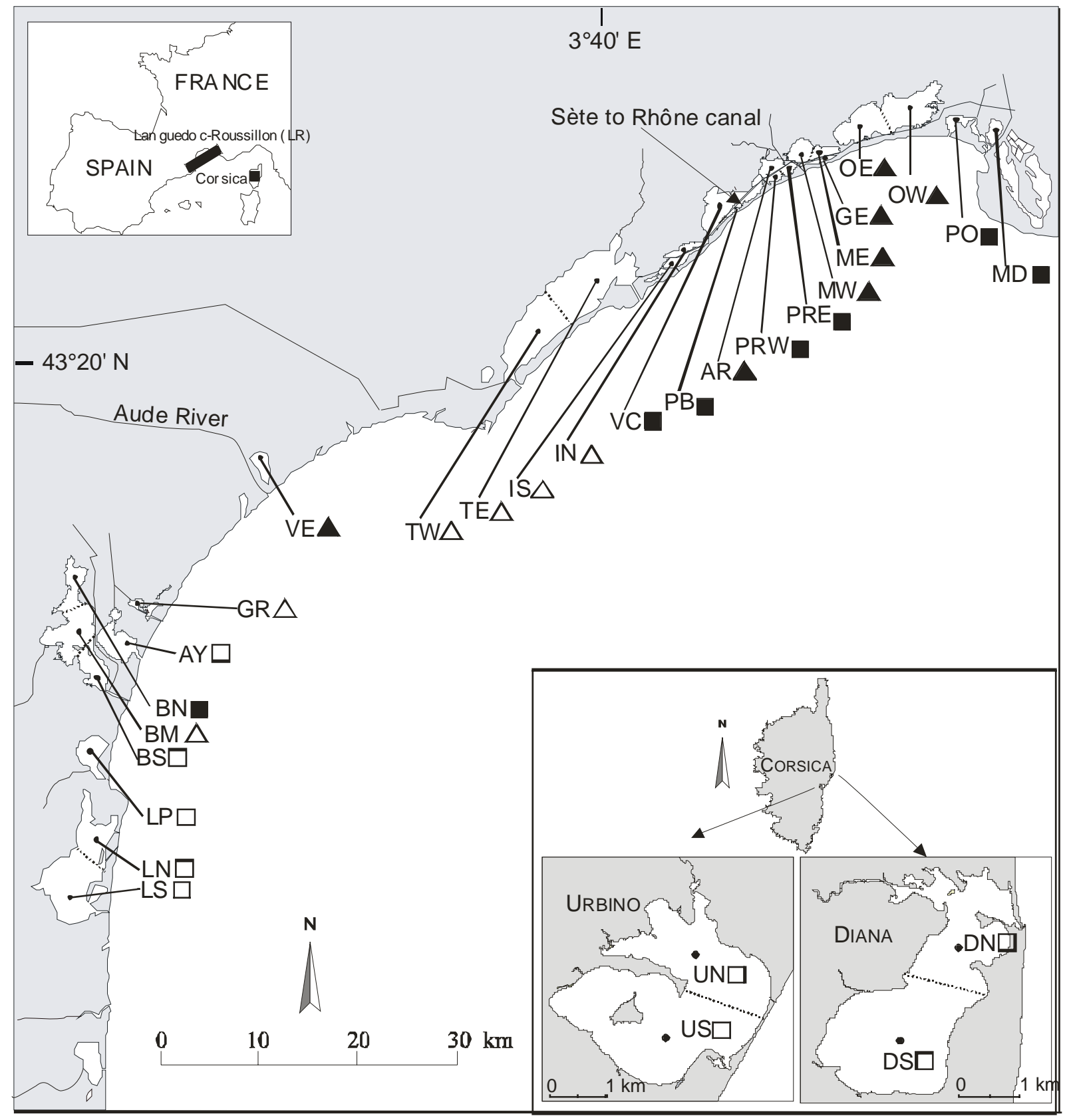


FIGURE 2

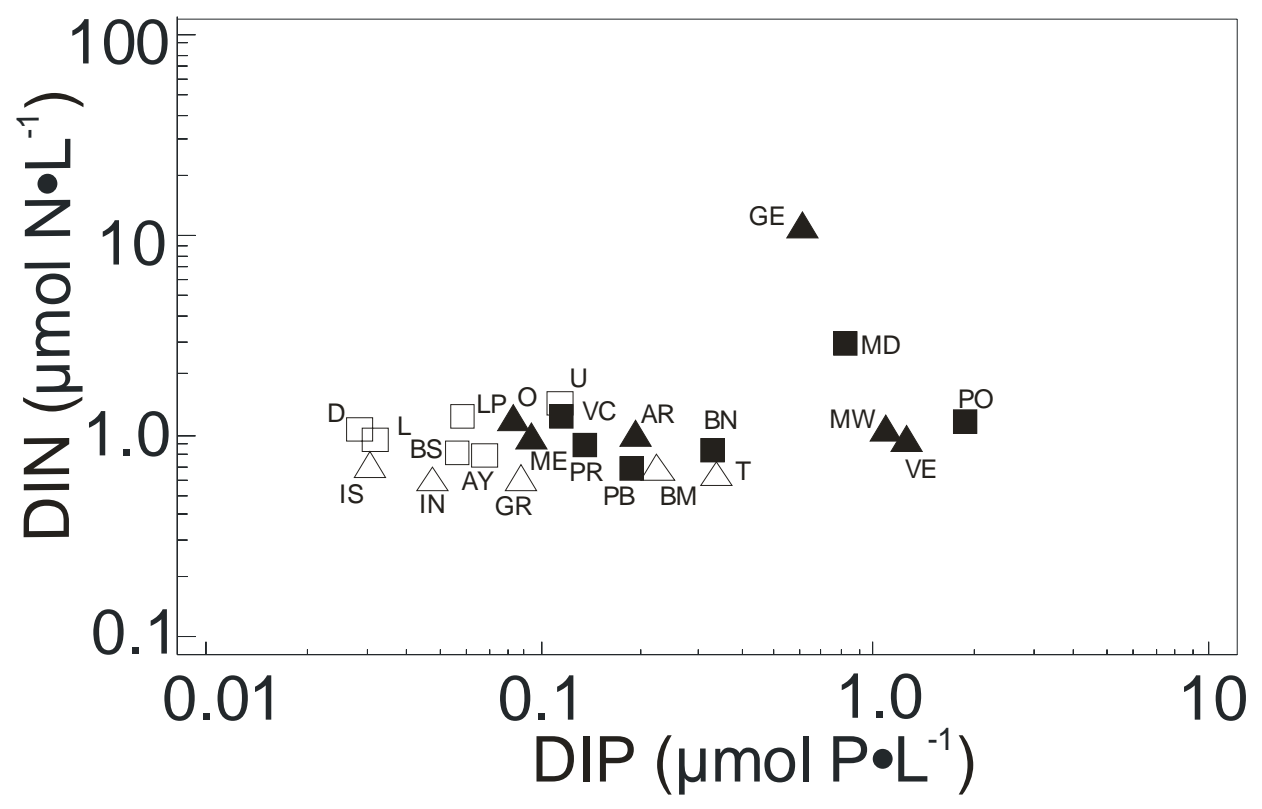


FIGURE 3

569

570

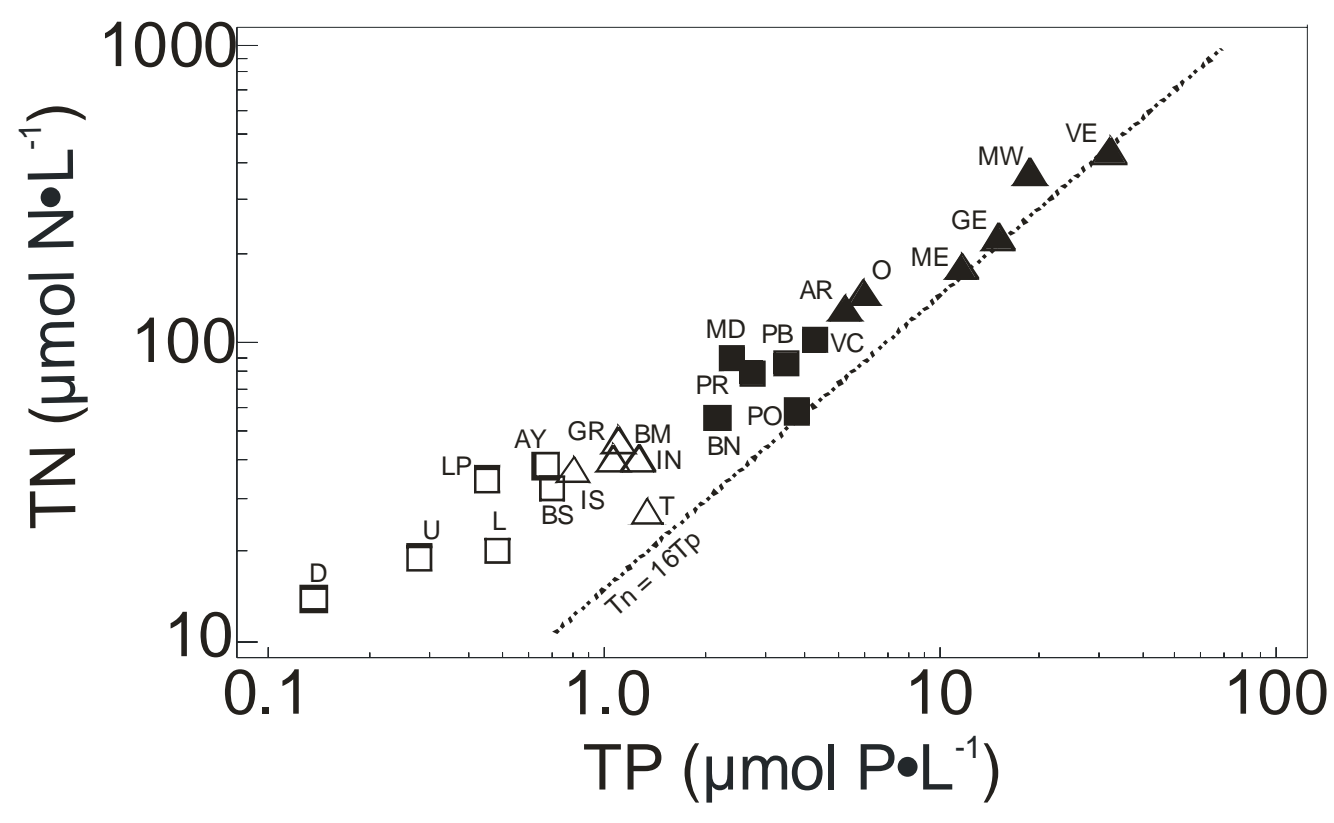


FIGURE 4

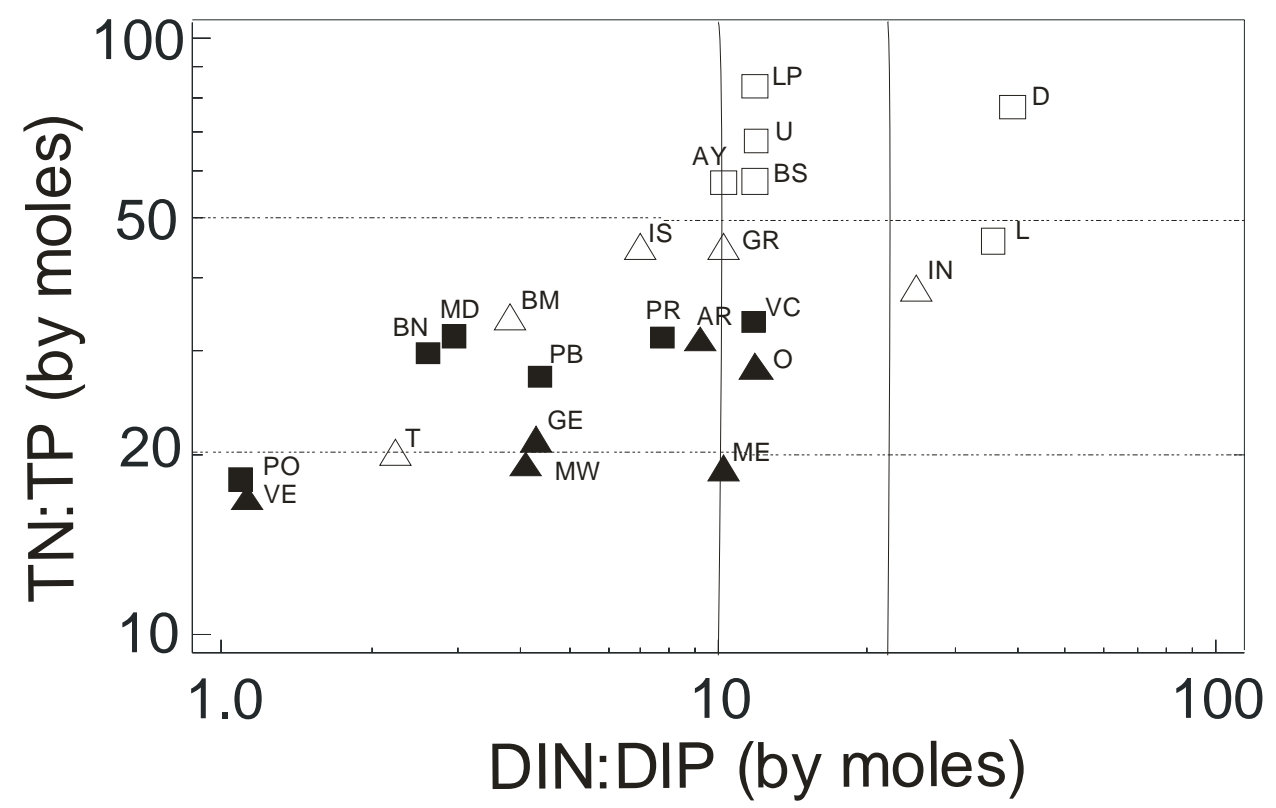




\section{FIGURE 5}

571

572

573

574

575

576
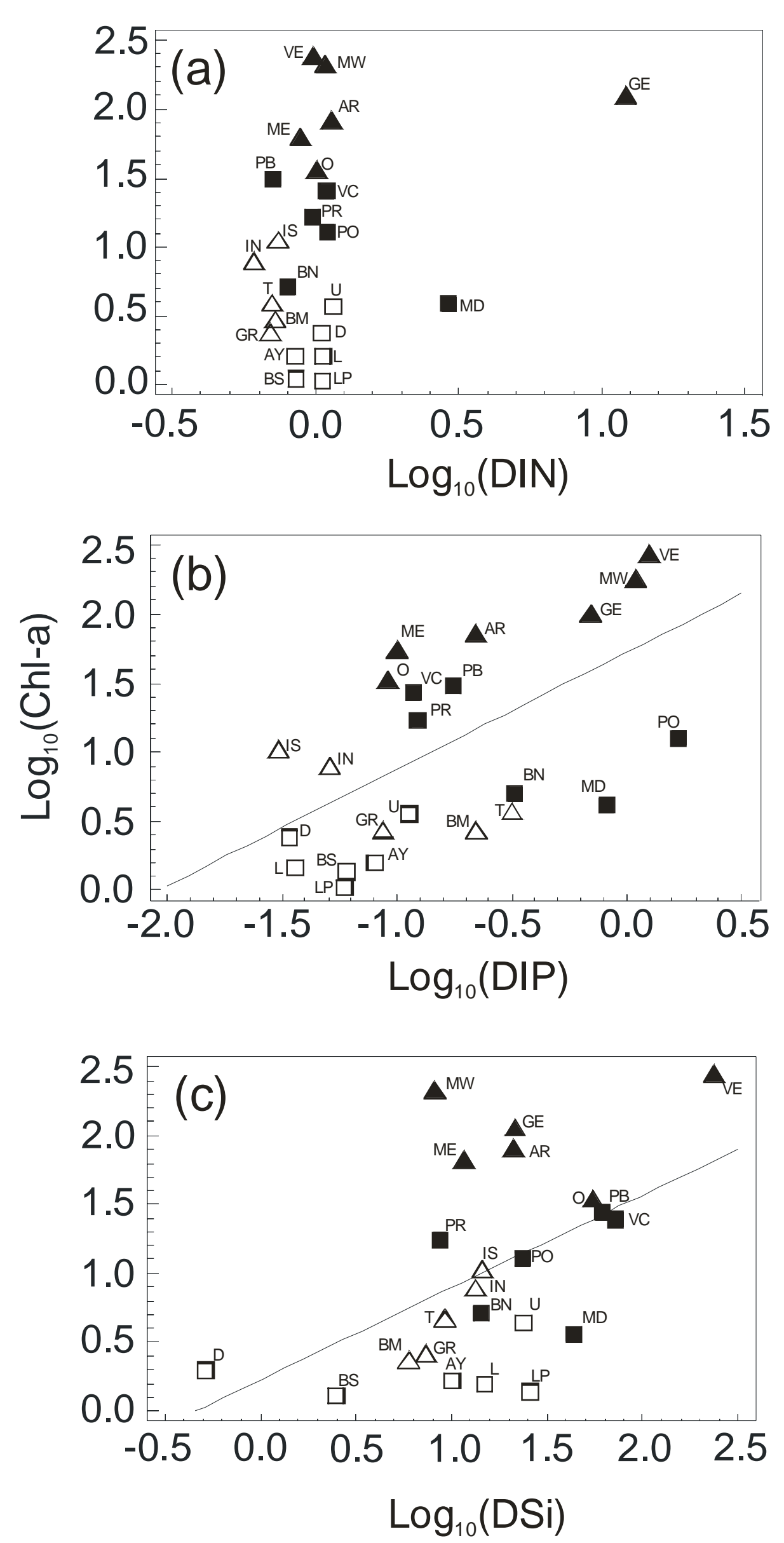
578

579

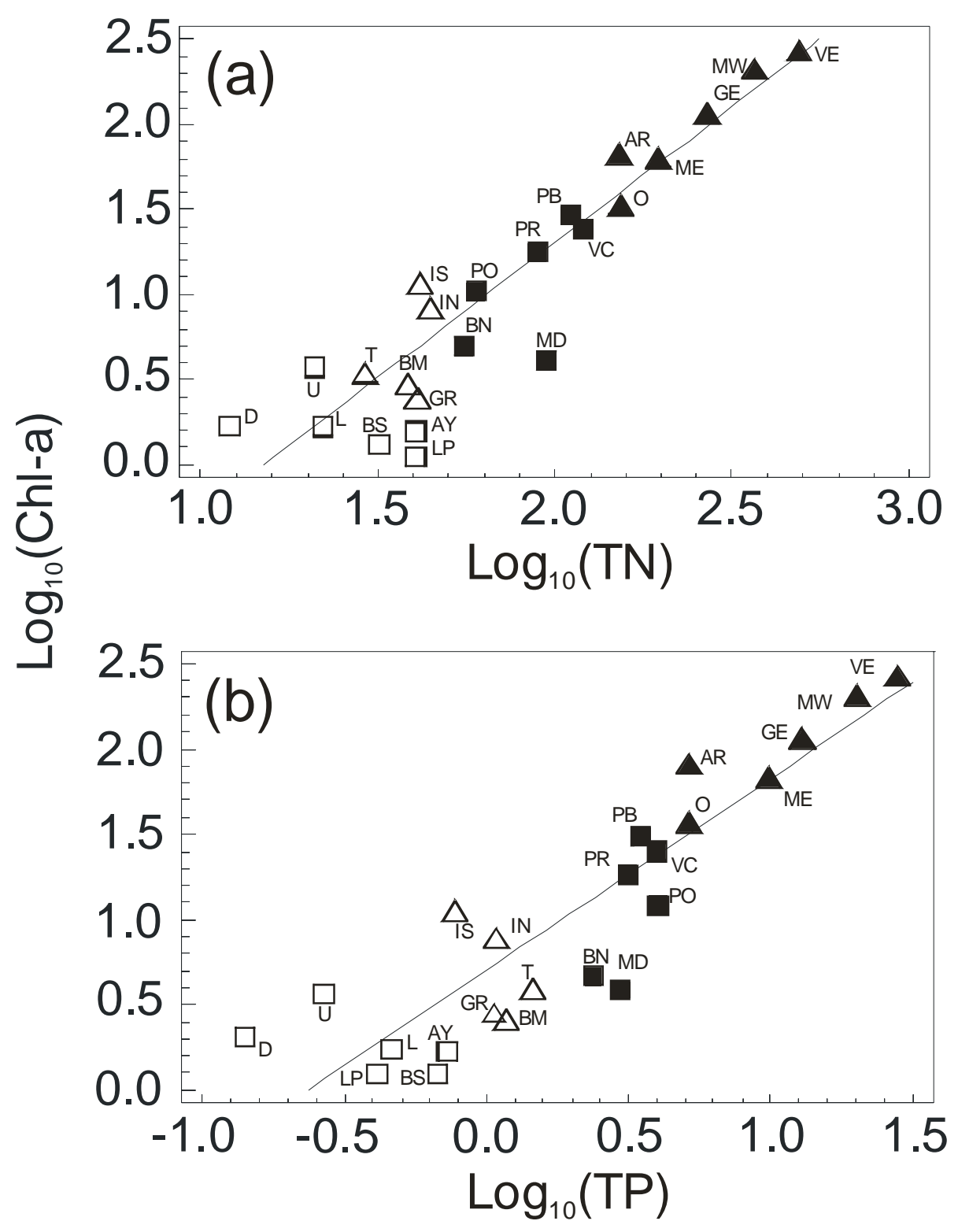

